\title{
Response Surface Modeling of Prickly Pear Juice Clarification
}

\author{
P. R. Davara ${ }^{1 *}$, A. K. Varshney ${ }^{1}$, V. A. Naliapara ${ }^{1}$ and V. P. Sangani ${ }^{1}$ \\ ${ }^{1}$ Dept. of Processing and Food Engg., College of Agril. Engg. and Technology, \\ Junagadh Agricultural University, Junagadh, Gujarat, India \\ Email : pareshdavara@yahoo.com
}

\begin{abstract}
Raw juice of prickly pear is viscous and turbid in nature. The clarity of such juice can be improved through enzymatic clarification. An experiment was conducted to standardize the process parameters for clarification of prickly pear juice using pectinase enzyme. Experiment was designed according to response surface methodology (RSM) by keeping three selected independnt variables at five different levels, i.e. enzyme concentrations (0.01, 0.026, 0.050, 0.074 and $0.09 \%$ ), incubation temperatures $\left(40,44,50,56\right.$ and $\left.60{ }^{\circ} \mathrm{C}\right)$, and incubation time $(60,84,120,156$ and $180 \mathrm{~min})$. Second order central composite rotatable design was employed to study the effect of enzymatic treatments on yield, viscosity, clarity, and turbidity of juice. Response surface modeling showed that the generated regression models were adequate to explain the data variation as well as the the actual relationship between independent variables and responses. The coefficient of determination, $\mathrm{R}^{2}$ values for all the selected parameters were greater than 0.9. Through response surface analysis, the optimum conditions for enzymatic clarification of prickly pear juice were established as $0.056 \%$ enzyme concentration, $47{ }^{\circ} \mathrm{C}$ incubation temperature, and $155 \mathrm{~min}$ incubation time. This interaction of process parameteres was able to improve the yield by up to $88.83 \%$ and clarity up to $52.86 \%$ as well as decreasing the viscosity by up to $1.60 \mathrm{cP}$, and turbidity by up to $123.02 \mathrm{NTU}$.
\end{abstract}

Keywords: Prickly pear, response surface modelling, juice clarification, pectinase enzyme, optimization

\section{Introduction}

Prickly pear belongs to the Cactaceae family. It is a wild fruit which grows under arid and semiarid conditions [34], [12], [30]. The demand of nutraceuticals, natural ingredients and health-promoting foods is continuously increasing. The variety of functional properties retained by prickly pear fruit fits well in this trend [30]. Fruit juices are very important in improving the human health [35]. The fruit juices market has substantially grown mainly due to the current trend of involving naturally healthy foods in our daily diets [49]. Prickly pear juices are rich in amino acids contents, particularly proline and taurine, and minerals such as calcium and magnesium which are considered as valuable ingredient for sports and energy drinks [36],[33]. The dark red colour of prickly pear juice makes it a valuable source for enhancing colour in fruit juice blends [27]. Prickly pear fruit has therefore received renewed interest for the production of juice.

The raw fruit juices contain suspended solids like earth, skin, stem and cellular debris from the fruit which makes it very turbid and unliked by the consumers. But, clarity of juice is of utmost importance from the consumers point of view. The particles suspended in the prepared juice spoil the presentation as well as affect the flavour of juice. The presence of polysaccharides such as pectin and starch is responsible for turbidity in the juice. Such juices had more characteristics of a puree than of a beverage and drinkability of it is reduced [37]. The clarity of the juices can be improved by removing the large pieces of debris through centrifugation. Though, it has not been found effective in the juice clarification and most of the small particles always remain in suspension. These suspended particles have to be removed to get a clear juice. Filteration is the alternative to remove these suspension, but some soluble pectin still remains in the juice, making it too viscous and difficult to filter quickly [23]. The complete enzymatic breakdown of pectin is the efficient way to produce clear and stable juice [21]. The most accepted method for removing the unwanted pectin is treating the fruit juices with pectinase [4], [6]. The controlling factors affetcting the enzymatic hydrolysis of pectic substances are type of enzyme, 
enzyme concentration, hydrolysis time, incubation temperature and $\mathrm{pH}$ [21], [40]. These factors are to be optimized to improve the recovery along with quality of juice. In view to this, the study was conducted to develop the protocol for clarification of prickly pear juice. The response surface modelling was done to establish the relationship between independent and response parameters.

Response surface methodology (RSM) has been used extensively by the reserchers for optimizing the process parameters in the fruit juice production [21], [40], [50], [52]. It reduces the number of experimental trials that need to evaluate multiple parameters and their interactions. In comparision to other approaches, it is less laborious and time-consuming. It has successfully demonstrated its usefulness in optimizing ingredients [8], [38], [48] and process variables [14], [24], [29], [39], [43],[47] or both [10], [52]. The aim of the study was to establish the optimum process conditions (enzyme concentration, incubation temperature and incubation time) for enzymatic clarification of prickly pear juice using response surface methodology and to study the effect of enzymatic treatements on yield, clarity, viscosity and turbidity of juice.

\section{$2 \quad$ Material and Methods}

\section{$2.1 \quad$ Fruit}

The fresh prickly pear fruit was collected from the plants grown at locally available farms and nearby areas of Junagadh (Gujarat, India). Fully ripe, bright red and purple colour fruits, without any visual defects, were selected for the experimental work.

\subsection{Enzyme Source}

Pectinase enzyme was used for the clarification of juice. It was purchased from HiMedia Laboratories Pvt. Ltd., Mumbai (Maharashtra, India) and was stored under refrigerated condition at $4{ }^{\circ} \mathrm{C}$. The activity of pectinase enzyme is $8000-12000 \mathrm{U} / \mathrm{g}$ with an optimum $\mathrm{pH}$ range of 5.0-5.5.

\subsection{Raw Material Preparation}

The fruits selected for the experiment were made free from the thorn by burning its thorn on flame and brushing them carefully on the abrasive surface without any damage to fruit. The dust and burn thorn particles on the fruit surface were then removed by washing it in the cool tap water. The damaged, defective, and over ripened fruits were not taken for the experimental work.

\subsection{Extraction of Pulp}

The cleaned prickly pear fruits were manually cut longitudinally into two halves to facilitate removal of seed and sub pulping. The longitudinally cut pulp was then scooped out with a sanitized spoon. Scooped pulp consisting of both, pulp and seeds, was put into a mixture grinder at low speed for 10-15 seconds just to facilitate the separation of seed from pulp. Enough care was taken during the grinding process to avoid the breakage of seeds. Whole mixture was then transferred to a domestic sieve having sieve size of 8 mesh for the separation of seeds from the pulp. The pure pulp without any seeds was finally used in the clarification process.

\subsection{Enzymatic Clarification}

The pure pulp of prickly pear fruit was very turbid due to presence of suspended pulp tissues as well as polysaccharides such as pectin and sugar. $100 \mathrm{~g}$ pulp was subjected to different enzymatic treatments under different conditions as shown in Table 1 . The independent variables were enzyme concentration, $\mathrm{X} 1$ (0.01-0.09\%), incubation temperature, $\mathrm{X} 2\left(40-60{ }^{\circ} \mathrm{C}\right)$ and incubation time, $\mathrm{X} 3$ (60-180 min). The flow chart in Fig. 1, illustrates the method used for enzymatic clarification of prickly pear juice. 
Table 1. Experimental design indicating coded and actual values of independent variables for enzymatic clarification of prickly pear juice.

\begin{tabular}{c|c|c|c|c|c|c}
\hline \multirow{2}{*}{$\begin{array}{c}\text { Treatment } \\
\text { No. }\end{array}$} & \multicolumn{3}{|c|}{ Coded values } & \multicolumn{3}{c}{ Actual values } \\
\cline { 2 - 7 } & $\mathrm{X}_{1}$ & $\mathrm{X}_{2}$ & $\mathrm{X}_{3}$ & Enzyme concentration $(\% \mathrm{w} / \mathrm{w})$ & Temperature $\left({ }^{\circ} \mathrm{C}\right)$ & $\begin{array}{c}\text { Time } \\
(\mathrm{min})\end{array}$ \\
\hline 1 & -1 & -1 & -1 & 0.026 & 44 & 84 \\
\hline 2 & 1 & -1 & -1 & 0.074 & 44 & 84 \\
\hline 3 & -1 & 1 & -1 & 0.026 & 56 & 84 \\
\hline 4 & 1 & 1 & -1 & 0.074 & 56 & 84 \\
\hline 5 & -1 & -1 & 1 & 0.026 & 44 & 156 \\
\hline 6 & 1 & -1 & 1 & 0.074 & 56 & 156 \\
\hline 7 & -1 & 1 & 1 & 0.026 & 56 & 156 \\
\hline 8 & 1 & 1 & 1 & 0.074 & 50 & 156 \\
\hline 9 & -1.682 & 0 & 0 & 0.010 & 50 & 120 \\
\hline 10 & 1.682 & 0 & 0 & 0.090 & 40 & 120 \\
\hline 11 & 0 & -1.682 & 0 & 0.050 & 60 & 120 \\
\hline 12 & 0 & 1.682 & 0 & 0.050 & 50 & 60 \\
\hline 13 & 0 & 0 & -1.682 & 0.050 & 50 & 180 \\
\hline 14 & 0 & 0 & 1.682 & 0.050 & 50 & 120 \\
\hline 15 & 0 & 0 & 0 & 0.050 & 50 & 120 \\
\hline 16 & 0 & 0 & 0 & 0.050 & 50 & 120 \\
\hline 17 & 0 & 0 & 0 & 0.050 & 50 & 120 \\
\hline 18 & 0 & 0 & 0 & 0.050 & 50 & 120 \\
\hline 19 & 0 & 0 & 0 & 0.050 & 50 & 120 \\
\hline 20 & 0 & 0 & 0 & 0.050 & &
\end{tabular}

\subsection{Juice Characteristics}

\subsubsection{Juice Yield}

The juice yield was calculated by taking the ratio of weight of clear juice and pulp weight. It was recorded in percent of juice.

$$
\text { Percent juice yield }=\frac{\text { Weight of clear juice }(g)}{\text { Weight of pulp }(g)} \times 100
$$

\subsubsection{Viscosity}

The viscosity measurement of clarified prickly pear juice samples was made using Brookfield Rheometer (DV III Ultra, Brookfield Engineering Laboratory, Inc., Middleboro, USA). Viscosity reading was taken at room temperature $\left(30 \pm 1^{\circ} \mathrm{C}\right)$ by rotating spindle $\mathrm{LV}-2$ at $100 \mathrm{rpm}$. It was recorded in centipoise $(\mathrm{cP})$.

\subsubsection{Clarity}

The clarity of juice was determined by using UV-VIS spectrophotometer (UV 5704SS, Electronics Corporation of India Pvt. Ltd., Hyderabad, India). The spectrophotometer was set at a wavelength of $660 \mathrm{~nm}$ and percent transmittance $(\% \mathrm{~T})$ was recorded by passing a light through the juice sample [21],[22]. Distilled water was used as a reference. 


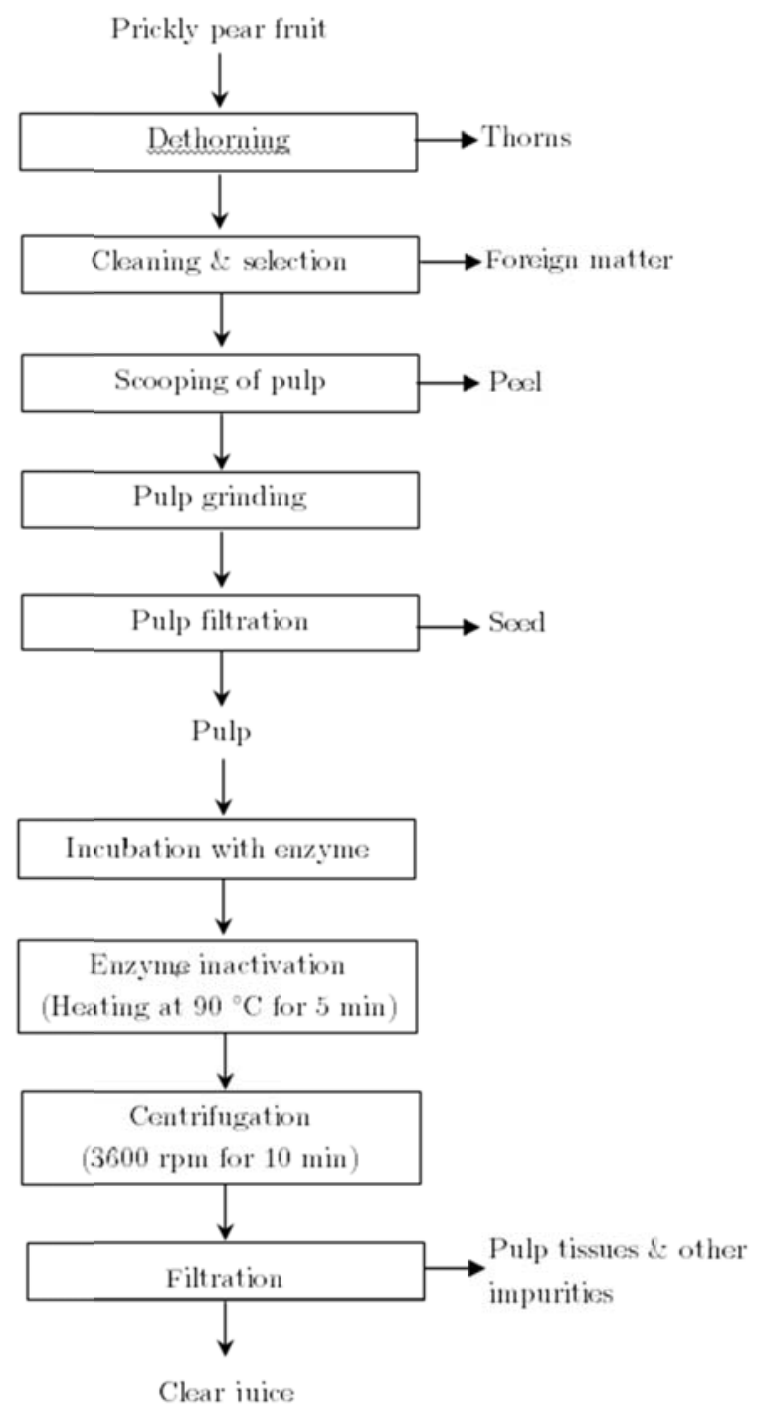

Figure 1. Flow chart for extraction and clarification of prickly pear juice.

\subsubsection{Turbidity}

Turbidity of juice was measured using a portable turbidity meter (T-100, OAKTON Instruments, Vernon Hills, IL 60061, USA) at room temperature [40]. The calibration of the instrument was done using calibration standards before it is to be used for measurement. Juice sample was thoroughly mixed to get the suspensded solids dispersed uniformly. It was then allowed to rest until all visible air bubbles disappeared. The sample was then poured into the cleaned sample vial up to the mark on the vial, capped and inverted twice to ensure even mixing. The vial containing the sample was wiped from outside, placed in the sample chamber and covered with vial cover. The measurement was then taken and expressed in Nephelometric Turbidity Units (NTU).

\subsubsection{Experimental Design and Statistical Analysis}

The experiment was designed adopting response surface methodology (RSM) [28],[18],[26]. The software package Design Expert version 8.0.0.6 (Trial version; STAT-EASE Inc., Minneapolis, MN, USA) was used to generate the experimental designs, statistical analysis and regression models. A three-factor five-level Central Composite Rotatable Design (CCRD) with quadratic model was employed to study the combined effect of three independent variables, viz., enzyme concentration (X1), incubation temperature (X2) and incubation time (X3) on different response variables. The: $\mathrm{pH}$ of the pulp was kept at its natural value, i.e. 5.05, and was not included in the RSM experimental design as this pH range is optimal for the exogenous pectinases [20]. Moreover, $\mathrm{pH}$ adjustment to alter clarification is not 
practiced commercially as described by [32]. Therefore, it was excluded from the RSM experimental design. Total 20 different combinations (Table 1) including six replicates of the centre point were carried out in random order according to CCRD configuration for the three chosen variables. The response function $(Y)$ was related to the coded variables by a second order polynomial equation given as below.

$$
Y=b_{0}+b_{1} X_{1}+b_{2} X_{2}+b_{3} X_{3}+b_{11} X_{11}+b_{22} X_{22}+b_{33} X_{33}+b_{12} X_{1} X_{2}+b_{13} X_{1} X_{3}+b_{23} X_{2} X_{3}
$$

The coefficients of polynomial were represented by $b_{0}$ (constant term), $b_{1}, b_{2}$ and $b_{3}$ (linear effects), $b_{11}$, $b_{22}$ and $b_{33}$ (quadratic effects), and $b_{12}, b_{13}$ and $b_{23}$ (interaction effects). Analysis of variance (ANOVA) tables were generated and the effect and regression coefficients of individual linear, quadratic and interaction terms were determined [18]. The significances of all terms in the polynomial were assessed statistically by computing the F-value at a probability (p) of $0.001,0.01$ or 0.05 . The regression coefficients were then used to make statistical calculation and to generate contour maps from the regression models. The three-dimensional (3D) response surface plots were generated by keeping one variable constant at the centre point and varying the other two variables within the experimental range.

\subsubsection{Optimization and Validation of Model}

The Design Expert version 8.0.0.6 software was used for the optimization of process variables. The optimum values of the selected variables were analyzed by the response surface contour plots and also by solving the regression equation. The optimum conditions obtained through response surface analysis were verified by conducting the experiments in triplicate. The average experimental value of different response variables were used to check the validity and adequacy of the predicted models.

\section{$3 \quad$ Results and Discussion}

\subsection{Statistical and Model Analysis}

The experimental values for yield, viscosity, clarity, and turbidity of prickly pear juice under different treatment conditions are reported in Table 2. The result of the regression analysis and analysis of variance (ANOVA) for all the models is reported in Table 3. The significant F-value and non-significant lack of fit indicates the fitness and reliability of the model for a given response. However, the adequacy of the model needed to be further checked by the coefficient of regression $\left(\mathrm{R}^{2}\right)[11]$. The closer the value of $\mathrm{R}^{2}$ to unity, the better the empirical model fits the actual data. The value of $\mathrm{R}^{2}$ greater than 0.8 implies that the model indicates a good fit [15]. Nevertheless, some researchers suggested that a large value of $\mathrm{R}^{2}$ does not always imply that the regression model is a good one. Increasing $\mathrm{R}^{2}$ can be obtained by adding a variable to the model. Thus, it is preferred to use an adjusted $\mathrm{R}^{2}$ to evaluate the model adequacy and it should be more than 0.8 [19]. Moreover, other parameters, namely predicted $\mathrm{R}^{2}$ which should be closer to value 1 and adequate precision which should be greater than 4 are supportive of the significance of the model [1]. The small values of C.V. give better reproducibility indicating the better precision and reliability of experiment. It is desirable to have a C.V. of less than $10 \%$.

Table 2. Juice characteristics influenced by different process variables.

\begin{tabular}{|c|c|c|c|c|c|c|c|}
\hline \multirow{3}{*}{$\begin{array}{l}\text { Sr. } \\
\text { No. }\end{array}$} & \multicolumn{3}{|c|}{ Independent Variables } & \multicolumn{4}{|c|}{ Responses } \\
\hline & $\begin{array}{c}\text { Enzyme Conc. } \\
(\%)\end{array}$ & Temp. $\left({ }^{\circ} \mathrm{C}\right)$ & $\begin{array}{l}\text { Time } \\
(\min )\end{array}$ & $\begin{array}{c}\text { Juice yield } \\
(\%)\end{array}$ & Viscosity $(\mathrm{cP})$ & Clarity $(\% \mathrm{~T})$ & Turbidity (NTU) \\
\hline & $X_{1}\left(x_{1}\right)$ & $X_{2}\left(x_{2}\right)$ & $X_{3}\left(x_{3}\right)$ & $Y_{1}$ & $Y_{2}$ & $Y_{3}$ & $Y_{4}$ \\
\hline 1 & $0.026(-1)$ & $44(-1)$ & $84(-1)$ & 86.67 & 1.68 & 46.31 & 153 \\
\hline 2 & $0.074(1)$ & $44(-1)$ & $84(-1)$ & 87.93 & 1.65 & 50.02 & 136 \\
\hline 3 & $0.026(-1)$ & $56(1)$ & $84(-1)$ & 86.16 & 1.66 & 45.75 & 177 \\
\hline 4 & $0.074(1)$ & $56(1)$ & $84(-1)$ & 87.26 & 1.67 & 42.12 & 169 \\
\hline 5 & $0.026(-1)$ & $44(-1)$ & $156(1)$ & 87.85 & 1.64 & 49.14 & 126 \\
\hline 6 & $0.074(1)$ & $44(-1)$ & $156(1)$ & 89.01 & 1.59 & 53.82 & 120 \\
\hline 7 & $0.026(-1)$ & $56(1)$ & $156(1)$ & 87.21 & 1.62 & 48.91 & 139 \\
\hline 8 & $0.074(1)$ & $56(1)$ & $156(1)$ & 88.27 & 1.63 & 46.48 & 142 \\
\hline
\end{tabular}




\begin{tabular}{c|c|c|c|c|c|c|c}
\hline 9 & $0.01(-1.682)$ & $50(0)$ & $120(0)$ & 86.12 & 1.65 & 46.21 & 149 \\
\hline 10 & $0.09(1.682)$ & $50(0)$ & $120(0)$ & 88.20 & 1.63 & 47.14 & 136 \\
\hline 11 & $0.05(0)$ & $40(-1.682)$ & $120(0)$ & 87.89 & 1.63 & 46.54 & 139 \\
\hline 12 & $0.05(0)$ & $60(1.682)$ & $120(0)$ & 87.00 & 1.65 & 40.09 & 168 \\
\hline 13 & $0.05(0)$ & $50(0)$ & $60(-1.682)$ & 87.09 & 1.69 & 46.87 & 162 \\
\hline 14 & $0.05(0)$ & $50(0)$ & $180(1.682)$ & 88.32 & 1.61 & 54.56 & 119 \\
\hline 15 & $0.05(0)$ & $50(0)$ & $120(0)$ & 88.41 & 1.61 & 48.92 & 132 \\
\hline 16 & $0.05(0)$ & $50(0)$ & $120(0)$ & 88.19 & 1.62 & 49.27 & 142 \\
\hline 17 & $0.05(0)$ & $50(0)$ & $120(0)$ & 88.12 & 1.60 & 48.70 & 139 \\
\hline 18 & $0.05(0)$ & $50(0)$ & $120(0)$ & 88.51 & 1.62 & 50.49 & 136 \\
\hline 19 & $0.05(0)$ & $50(0)$ & $120(0)$ & 88.28 & 1.61 & 49.22 & 140 \\
\hline 20 & $0.05(0)$ & $50(0)$ & $120(0)$ & 88.46 & 1.61 & 50.67 & 143 \\
\hline
\end{tabular}

Model analysis was done for checking its validity. Looking to the values of various statistical indicateors, such as F-value, coefficient of determination $\left(\mathrm{R}^{2}\right)$ and coefficient of variation (C.V.) as given in Table 3, all the models were found statistically adequate. The significant F-value $(\mathrm{p}<0.001)$ and nonsignificant lack of fit $(\mathrm{p}<0.05)$ for yield, viscosity, clarity and turbidity of prickly pear juice concluded that all the models were fitted. The higher $\mathrm{R}^{2}$ and $\mathrm{Adj}-\mathrm{R}^{2}$ values (greater than 0.8 ) for all the selected responses indicated the adequacy, good fit and high significance of the model. The analysis of variance (ANOVA) of four response variables, i.e., yield, viscosity, clarity and turbidity showed that experimental data had correlation coefficients $\left(\mathrm{R}^{2}\right)$ of $0.9740,0.9708,0.9626$ and 0.9755 , respectively with the calculated model. That means the calculated model was able to explain 97.40, 97.08, 96.26 and $97.55 \%$ of the results in case of yield, viscosity, clarity and turbidity, respectively. Pred-R ${ }^{2}$ value was also in reasonable agreement with the $\mathrm{Adj}-\mathrm{R}^{2}$ for all the parameters. The Adeq Precision value greater than 4 further highlighted the significance of the model for all the dependent variables. The small value of C.V. $(<10 \%)$ for all the variables explained that the experimental results were precise and reliable. Neglecting the non-significant parameters, the final predictive equations obtained were given as below:

Juice yield $=88.323+0.592 \mathrm{X} 1-0.297 \mathrm{X} 2+0.468 \mathrm{X} 3-0.379 \mathrm{X}^{2}-0.278 \mathrm{X} 2^{2}+0.186 \mathrm{X} 3^{2}-0.032 \mathrm{X} 1 \mathrm{X} 2$

Viscosity $=1.612-0.007 \mathrm{X} 1+0.004 \mathrm{X} 2-0.023 \mathrm{X} 3+0.009 \mathrm{X} 1^{2}+0.009 \mathrm{X} 2^{2}+0.013 \mathrm{X} 3^{2}+0.013 \mathrm{X} 1 \mathrm{X} 2$

$$
\text { Clarity }=49.51-1.968 \mathrm{X} 2+1.983 \mathrm{X} 3-0.787 \mathrm{X} 1^{2}-1.975 \mathrm{X} 2^{2}+0.641 \mathrm{X} 3^{2}-1.806 \mathrm{X} 1 \mathrm{X} 2
$$

Turbidity $=138.688-3.651 \mathrm{X} 1+10.308 \mathrm{X} 2-13.203 \mathrm{X} 3+5.104 \mathrm{X} 2^{2}$

$$
+2.25 \mathrm{X} 1 \mathrm{X} 2+2.75 \mathrm{X} 1 \mathrm{X} 3-2.75 \mathrm{X} 2 \mathrm{X} 3
$$

where, X1, X2 and X3 are the coded factors of enzyme concentration, incubation temperature and incubation time, respectively.

Table 3. Regression coefficients, R2 and p values for different response variables for enzymatic clarification of prickly pear juice.

\begin{tabular}{l|c|c|c|c}
\hline Source & $\begin{array}{c}\text { Juice yield } \\
(\%)\end{array}$ & $\begin{array}{c}\text { Viscosity } \\
(\mathrm{cP})\end{array}$ & $\begin{array}{c}\text { Clarity } \\
(\% \mathrm{~T})\end{array}$ & $\begin{array}{c}\text { Turbidity } \\
(\mathrm{NTU})\end{array}$ \\
\hline $\mathrm{b}_{0}$ & $88.323^{* * *}$ & $1.612^{* * *}$ & $49.51^{* * *}$ & $138.688^{* * *}$ \\
\hline Linear terms & $0.592^{* * *}$ & $-0.007^{* *}$ & 0.285 & $-3.651^{* *}$ \\
\hline $\mathrm{b}_{1}\left(\mathrm{X}_{1}\right)$ & $-0.297^{* * *}$ & $0.004^{*}$ & $-1.968^{* * *}$ & $10.308^{* * *}$ \\
\hline $\mathrm{b}_{2}\left(\mathrm{X}_{2}\right)$ & $0.468^{* * *}$ & $-0.023^{* * *}$ & $1.983^{* * *}$ & $-13.203^{* * *}$ \\
\hline $\mathrm{b}_{3}\left(\mathrm{X}_{3}\right)$ & -0.032 & $0.013^{* * *}$ & $-1.806^{* * *}$ & 2.25 \\
\hline Interaction terms & -0.017 & -0.003 & 0.271 & $2.75^{*}$ \\
\hline $\mathrm{b}_{12}\left(\mathrm{X}_{1} \mathrm{X}_{2}\right)$ & -0.025 & 0.002 & 0.111 & $-2.75^{*}$ \\
\hline $\mathrm{b}_{13}\left(\mathrm{X}_{1} \mathrm{X}_{3}\right)$ & \multicolumn{5}{|l}{} \\
\hline $\mathrm{b}_{23}\left(\mathrm{X}_{2} \mathrm{X}_{3}\right)$ & $\mathrm{Quadratic} \mathrm{terms}^{5}$ &
\end{tabular}




\begin{tabular}{|c|c|c|c|c|}
\hline $\mathrm{b}_{11}\left(\mathrm{X}_{1}^{2}\right)$ & $-0.379^{* * *}$ & $0.009^{* * *}$ & $-0.787^{* *}$ & 1.215 \\
\hline $\mathrm{b}_{22}\left(\mathrm{X}_{2}^{2}\right)$ & $-0.278^{* * *}$ & $0.009^{* * *}$ & $-1.975^{* * *}$ & $5.104^{* * *}$ \\
\hline $\mathrm{b}_{33}\left(\mathrm{X}_{3}^{2}\right)$ & $0.186^{* *}$ & $0.013^{* * *}$ & $0.641^{*}$ & 0.508 \\
\hline \multicolumn{5}{|c|}{ Indicators for model fitting } \\
\hline $\mathrm{R}^{2}$ & 0.9740 & 0.9708 & 0.9626 & 0.9755 \\
\hline $\operatorname{Adj-R^{2}}$ & 0.9505 & 0.9445 & 0.9288 & 0.9535 \\
\hline Pred- $\mathrm{R}^{2}$ & 0.8627 & 0.8968 & 0.8147 & 0.9239 \\
\hline Adeq. Precision & 21.299 & 20.949 & 22.109 & 24.261 \\
\hline F-value & 41.55 & 36.94 & 28.56 & 44.30 \\
\hline Lack of Fit & NS & NS & NS & NS \\
\hline C.V., \% & 0.21 & 0.39 & 1.87 & 2.36 \\
\hline
\end{tabular}

\subsection{Effect of Enzyme Concentration, Temperature and Time}

The effect of enzyme concentration, temperature, and time on the dependent variables is explained by coefficient of the second order polynomials. The response surface curves as well as contour plots for different response variables are shown in Figure 2 to Figure 5.

\subsubsection{Juice Yield}

For the juice yield, the linear effect of enzyme concentration and incubation time was positive but the linear effect of incubation temperature was negative, which all were significant at $\mathrm{p}<0.001$. Whilst, the quadratic effect enzyme concentration and incubation temperature, was significantly negative at $\mathrm{p}<0.001$ and it was positively significant at $\mathrm{p}<0.01$ for incubation time. However, all the interaction effects were found non-significant for the juice yield.

The interactive effect of enzyme concentration and temperature on the juice yield at constant time is presented in Fig. 2. Contour plot indicated that the juice yield was increased with an increase in enzyme concentration up to $0.069 \%$ and temperature up to $47{ }^{\circ} \mathrm{C}$. At this combination the juice yield was expected to be improved up to $88.65 \%$. Further rise in temperature decreased the yield. Slight decrease in yield was observed with an increase in enzyme concentration beyond $0.069 \%$. The decrease in juice yield beyond $47^{\circ} \mathrm{C}$ might be due to the denaturation of protein which led to decrease in enzyme activity. The increase in juice yield with increasing pectinase enzyme concentration was also supported by [31] who reported that pectinases degraded the pectic substances leading to increase in juice yield. [41] also found the increase in plum juice yield from $48 \%$ to $77.5 \%$ with an increase in enzyme concentration.
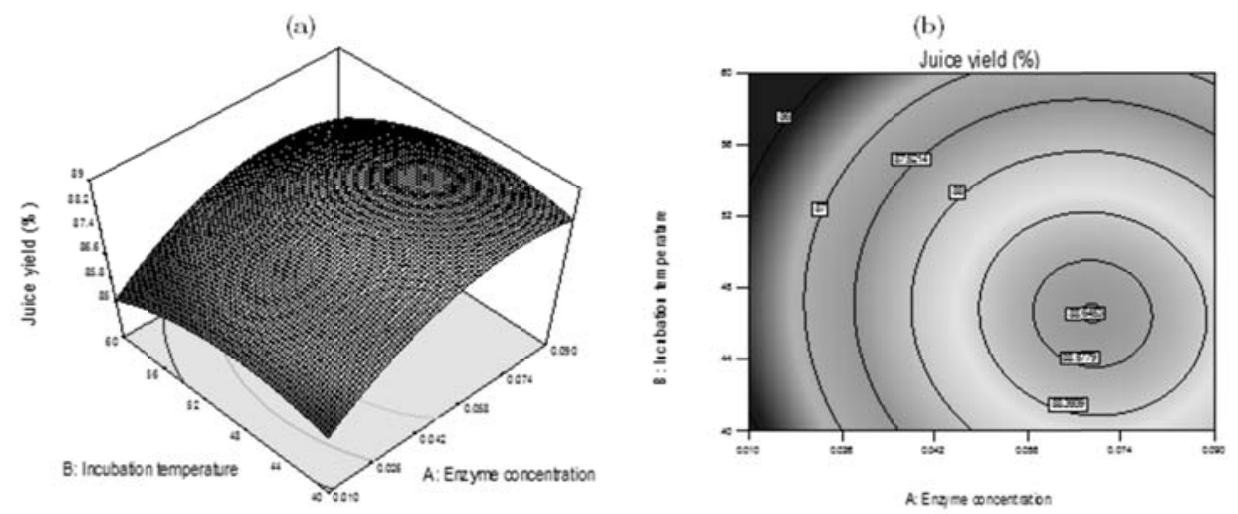

Figure 2. Three dimensional plot (a) and contour plot (b) for the effect of enzyme concentration and incubation temperature at constant time of $120 \mathrm{~min}$ on juice yield.

\subsubsection{Viscosity}


Fruit pulps generally present non-newtonian rheological behavior [45]. Researchers [3],[46] found that the use of enzymes leads to the drop of fruit juice viscosity, as well as improving pressability of the pulp, disintegrating the jelly structure and making it easier to obtain the fruit juices. The linear effect of viscosity was significantly affected by enzyme concentration and time at $\mathrm{p}<0.01$ and $\mathrm{p}<0.001$, respectively followed by temperature $(\mathrm{p}<0.05)$. The quadratic effects of all the independent variables were significantly positive at $\mathrm{p}<0.001$. The interaction of enzyme concentration and temperature showed positive and significant effect at $\mathrm{p}<0.001$ which indicated that the enzyme concentration was dependent on incubation temperature.

The response surface curve and contour plot showing the variation in the viscosity of juice as a function of enzyme concentration and temperature is presented in Fig. 3. The figure reflected the decrease in viscosity as the enzyme concentration increased up to $0.072 \%$ and temperature up to $45^{\circ} \mathrm{C}$. The viscosity at this combination was proposed to be decreased up to $1.61 \mathrm{cP}$. With further increase in enzyme concentration, the viscosity of juice increased slightly whereas it increased linearly with an increase in temperature up to its maximum level. [16] reported the increase in viscosity of the blended carrot-orange juice with increase in temperature beyond $45{ }^{\circ} \mathrm{C}$. [21] observed that the viscosity of juice decreased with increase in enzyme concentration from $0.01 \%$ to its maximum value $(0.1 \%)$.
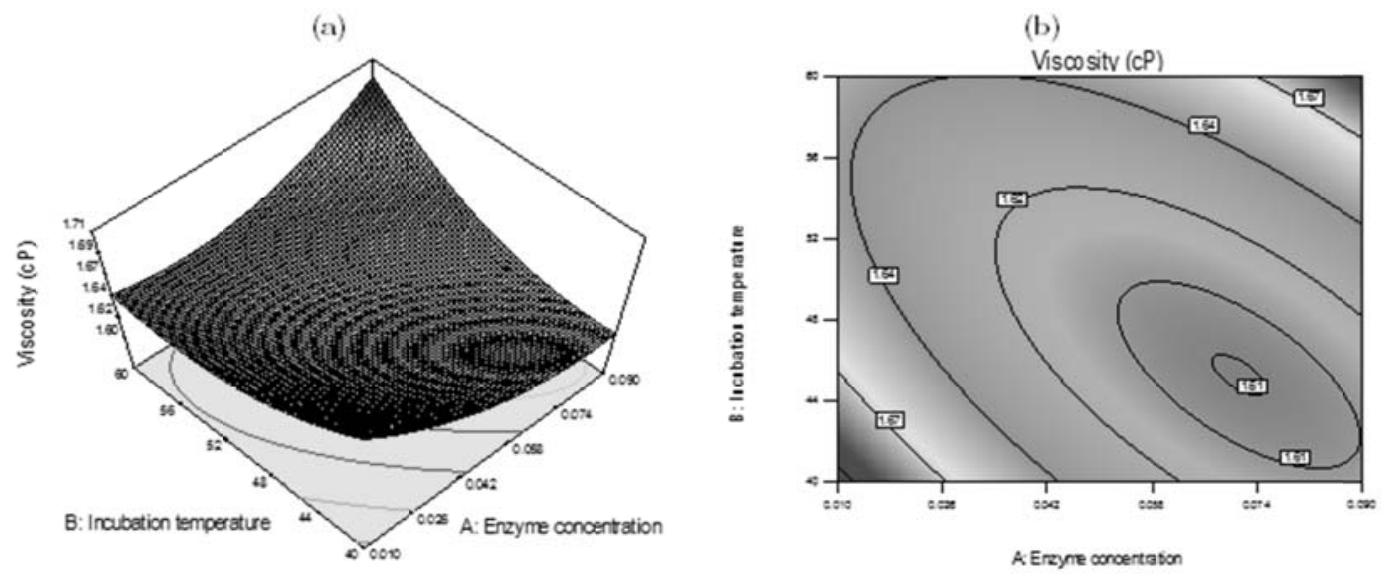

Figure 3. Three dimensional plot (a) and contour plot (b) for the effect of enzyme concentration and incubation temperature at constant time of $120 \mathrm{~min}$ on viscosity of juice.

\subsubsection{Clarity}

Clarity is one of the essential requirement for the clarified juice [40]. Clarified juice is a natural juice that is pulpless and do not have cloudy appearance [22]. Upon enzyme treatment, pectolytic enzymes breakdown the pectin molecules, which facilitate the formationof pectin-protein flocs, leaving a clear supernatant and significantly removing the colloidal aspect of the juices [2],[51]. The linear effects of time and temperature were significant $(\mathrm{p}<0.001)$ on clarity of juice. The quadratic effects of enzyme concentration, temperature and time were significant at $\mathrm{p}<0.001$ or $\mathrm{p}<0.01$. Only, the interaction effect between enzyme concentration and temperature was significant $(\mathrm{p}<0.001)$ which indicated the dependency of enzyme concentration on incubation temperature.

The interaction effect of temperature and time on clarity of juice as shown in Fig. 4, reveals that the clarity of juice was increased with an increase in the enzyme concentration and incubation temperature up to $0.087 \%$ and $43{ }^{\circ} \mathrm{C}$, respectively. 

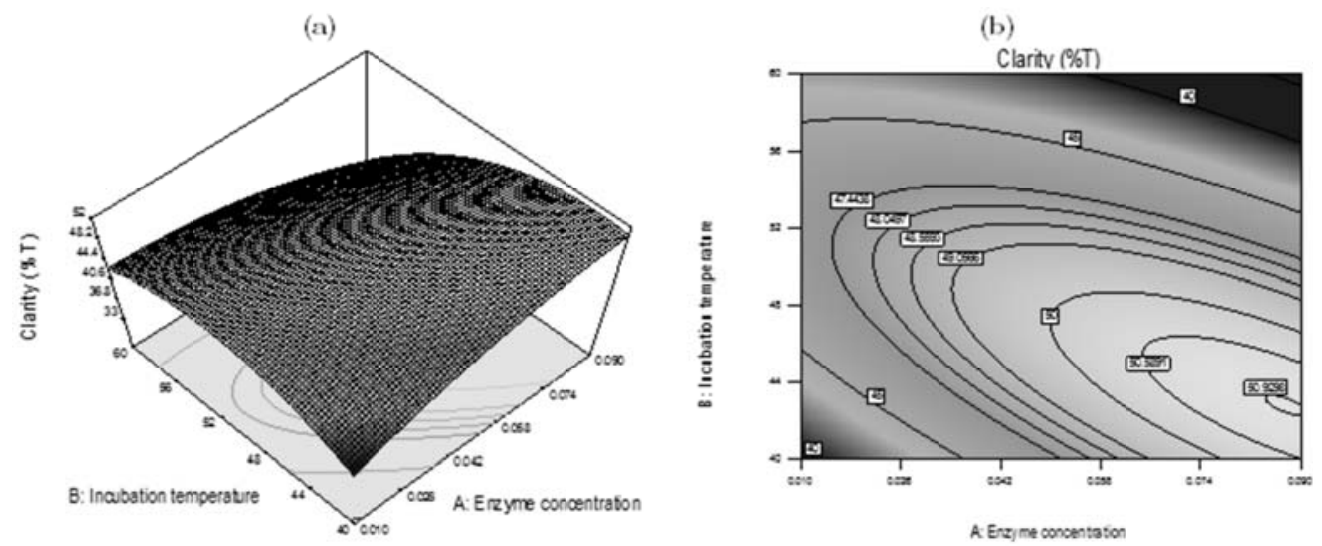

Figure 4. Three dimensional plot (a) and contour plot (b) for the effect of enzyme concentration and incubation temperature at constant time of 120 min on clarity of juice.

The temperature increases the rate of enzymatic reactions, hence the rate of clarification, as long as the temperature is below denaturation temperature for the enzyme [21]. The clarity of juice was expected to be increased up to $50.94 \%$ at this combination of enzyme concentration and temperature. Upon further increase in enzyme concentration, the clarity of juice remained unaffected whereas it decreased considerably with an increase in temperature up to its maximum level. [42] also found the analogous result on the clarity of juice from bael fruit. The degradation of polysaccharides like pectin led to a reduction in water holding capacity and consequently, free water was releasedl to the system which increased the clarity of juice [6]. The other reason for the increase in clarity of juice was the increase in enzyme concentration. It may increase the rate of clarification by exposing part of the positively charged protein beneath. Thus, electrostatic repulsion between cloud particles was reducerd which caused these particles to aggregate into larger particles and eventually settled out [40].

\subsubsection{Turbidity}

In clarified fruit juices, a juice that has anunstable cloud or whose turbidity is not desirable isconsidered "muddy" and is unacceptable to be marketed as clear juices [7]. Turbidity directlyindicates unsettle matter or impurities in water suspension, such as colloidal polysaccharide particles in fresh juices [9]. For orange and tomatojuices, this property is a positive sensorial aspect, whereas for pear, guava, apple and carambola juices it is a negativeone [22],[5],[13],[17],[25],[40]. Table 3 reveals that enzyme concentration and time showed negative linear effect on turbidity at $\mathrm{p}<0.01$ and $\mathrm{p}<0.001$, respectively. The incubation temperature showed significantly positive effect on tturbidity at $\mathrm{p}<0.001$. The quadratic effect of incubation temperature was only significant at $\mathrm{p}<0.001$. The interaction effects of time with enzyme concentration and temperature were significant at $\mathrm{p}<0.05$. This means that the action of enzyme was dependent on the incubation temperature during enzymatic clarification of prickly pear juice.

In general, enzyme concentration was the main factor influencing the clarification of prickly pear juice. However, the temperature was found to be the equal important parameter, since the model showed a significant effect on linear, quadric and interactive regressions for turbidity. Fig. 5 shows threedimensional and contour plot for the turbidity as a function of enzyme concentration and incubation temperature. The figure indicated that the turbidity of juice was decreased with an increase in the enzyme concentration up to its maximum level $(0.09 \%)$ and incubation temperature up to $42{ }^{\circ} \mathrm{C}$, respectively. At this combination, the turbidity of juice was believed to be reduced up to $126.27 \mathrm{NTU}$. The further increase in temperature showed an increase in turbidity. [9] stated that the pectin is the main cause of turbidity in the fruit juices. As the clarification process took place, the amount of pectin in the juices decreased, therefore reducing the turbidity of the juices [2]. In fact, long exposition to high enzyme concentrations were likely to breakdown pectic substances exposing positive nucleus sites to surrounding negative charges, settling out the so formed large protein-pectin particles [17]. 

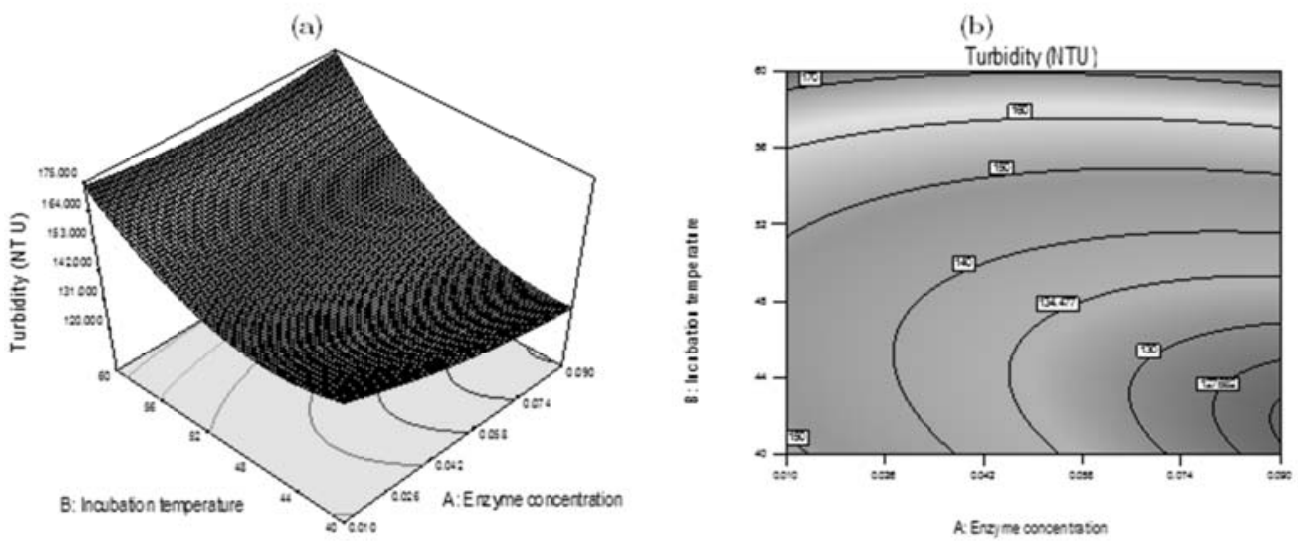

Figure 5. Three dimensional plot (a) and contour plot (b) for the effect of enzyme concentration and incubation temperature at constant time of 120 min on turbidity of juice.

\subsection{Optimization and Validation of Process Variables}

The process economy is a decisive factor needed to be taken into consideration in order to achieve a reasonable operational condition [44]. Among the different independent variables, enzyme concentration is the limiting factor affecting the cost of processing. To make the process economical with an ideal processing condition, optimization was carried out by keeping the criteria for enzyme concentrations at lower level. As a consequence, the main criteria choosen for process optimization were: (a) enzyme concentration : minimum, (b) yield : maximum, (c) viscosity : minimum, (d) clarity : maximum, (e) turbidity : minimum as illustrated in Table 4.

Table 4. Optimization of process variables with respect to juice yield, viscosity, clarity and turbidity.

\begin{tabular}{|c|c|c|c|c|c|c|}
\hline \multicolumn{7}{|c|}{ Variables } \\
\hline \multicolumn{2}{|c|}{ Constraint } & Goal & \multicolumn{2}{|c|}{ Importance } & \multicolumn{2}{|c|}{ Optimum value } \\
\hline \multicolumn{2}{|l|}{ Enzyme concentration (\%) } & Minimize & \multicolumn{2}{|r|}{3} & \multicolumn{2}{|c|}{0.056} \\
\hline \multicolumn{2}{|c|}{ Incubation temperature $\left({ }^{\circ} \mathrm{C}\right)$} & \multirow{2}{*}{$\begin{array}{l}\text { In the range } \\
\text { In the range }\end{array}$} & \multicolumn{2}{|r|}{3} & \multicolumn{2}{|r|}{47} \\
\hline \multicolumn{2}{|c|}{ Incubation time $(\min )$} & & & 3 & & 155 \\
\hline \multicolumn{7}{|c|}{ Responses } \\
\hline Constraint & Goal & Importance & $\begin{array}{c}\text { Predicted } \\
\text { value }\end{array}$ & \multicolumn{2}{|c|}{ Experimental value } & Deviation $(\%)$ \\
\hline Juice yield (\%) & Maximize & 3 & 88.83 & \multicolumn{2}{|c|}{87.16} & 1.88 \\
\hline Viscosity $(\mathrm{cP})$ & Minimize & 3 & 1.60 & \multicolumn{2}{|l|}{1.62} & 1.25 \\
\hline Clarity (\% $\mathrm{T})$ & Maximize & 3 & 52.87 & \multicolumn{2}{|c|}{51.14} & 3.27 \\
\hline Turbidity (NTU) & Minimize & 3 & 123.00 & \multicolumn{2}{|c|}{119.65} & 2.72 \\
\hline Desirability & -- & -- & 0.797 & \multicolumn{2}{|l|}{--} & -- \\
\hline
\end{tabular}

Upon these inputs, the optimum treatment conditions were found to be, $0.056 \%$ enzyme concentration, $47^{\circ} \mathrm{C}$ incubation temperature, and 155 min incubation time. The predictive study indicated that at this combination of enzyme concentration, incubation temperature and incubation time, it would be possible to produce juice with a yield of $88.83 \%$, viscosity of $1.60 \mathrm{cP}$, clarity of $52.87 \% \mathrm{~T}$ and turbidity of 123.00 NTU. For these optimized conditions, the experiments were repeated to check the deviation in the predicted and experimental values of different response variables. Neglible and accieptable deviation was observed between experimental and predicted values. The experimental values were fairly close to the 
predicted values (Table 4). This implied that there was a high degree of fit between the observed and predicted values from the regression models and each model was quite accurate in prediction. The least variation in the actual and predicted responses justified that the model as developed from the experiment is valid.

\section{Conclusions}

The process variables (enzyme concentration, incubation temperature and incubation time) were optimized for enzymatic clarification of prickly pear juice. Regression models were generated to establish the correlation between independent variables and response parameters. The different combinations of controlled factors showed their noticiable effect on the juice yield, viscosity, clarity, and turbidity of the prickly pear juice. The yield and clarity were improved while the viscosity and turbidity were decreased upon enzymatic treatement. The optimum combination of processing variables can be obtained graphically in the form of three dimensional and contour plots through response surface analysis. It may be helpful to derive the suitble pretreatment levels for efficient clarificatioin of prickly pear juice. The enzyme concentration of $0.056 \%$, incubation temperature of $47{ }^{\circ} \mathrm{C}$ and incubation time of 155 min are suggested to obtain the better quality of prickly pear juice.

\section{References}

1. Akesowan, A. and Choonhahirun, A. "Effect of enzyme treatment on guava juice production using Response surface methodology." The Journal of Animal and Plant Sciences, vol. 23, no. 1, pp. 114-120, 2013.

2. Alvarez, S., Alvarez, R., Riera, F.A. and Coca, J. "Influence of depectinization on apple juice ultrafiltration." Colloids and Surfaces A: Physicochemical and Engineering Aspects, vol. 138, pp. 377-382, 1998.

3. Carneiro, L., Sa, I.D., Gomes, F.D., Matta, V.M. and Cabral, L.M.C. "Cold sterilization and clarification of pineapple juice by tangential microfiltration." Desalination, vol. 148, pp. 92-98, 2002.

4. Cemeroğlu, B. andKaradeniz, F. Meyve Suyu Üretim Teknolojisi, (GıdaTeknolojisi Derneği Yayınları) Ankara, 25, pp. 41-45, 2001.

5. Chopda, C.A. and Barrett, D.M. "Optimization of guava juice and powder." Journal of Food Processing and Preservation, vol. 25, pp. 411-430, 2001.

6. Demir, N., Acar, J., Sarıŏlu, K. and Mutlu, M. "The use of commercial pectinase in fruit juice industry." Part 3: Immobilized pectinase for mash treatment, Journal of Food Engineering, vol. 47, pp. 275-280, 2001.

7. Floribeth, V., Celsa, L. and Cooke, R.D. "A study of the production of clarified banana juice using pectolytic enzymes." Food Technology, vol. 16, pp. 115-125, 1981.

8. Gallagher, E., O'Brien, C.M., Scannell, A.G.M. and Arendt, E.K. "Use of response surface methodology to produce functional short dough biscuits." Journal of Food Engineering, 56, 269-271, 2003.

9. Grassin, C. and Fauquembergue, P. Enzymes, fruit juice processing. In Encyclopedia of bioprocess technology : fermentation, biocatalysis, bioseparation (Flickinger, M. C. and Drew, S. W., Eds.), John Wiley and Sons, Inc., New York, pp. 1030-1061, 1999.

10.Guerrero, S.N. and Alzamora, S.M."Effect of pH, temperature and glucose addition on flow behavior of fruit purees." Journal of Food Engineering, vol. 33, pp. 239-256, 1997.

11.Haber, A. and Runyon, R. General statistics (3rd Ed.), Addison-Wesley, Reading, MA, 1977.

12.Inglese P., Basile, F. and Schirra, M. Cactus pear fruit production. In: Nobel, P. (Ed.), Cacti: Biology and Uses, University of California Press, California, USA, Chapter $10: 163-183,2002$.

13.Isabella, M.B., Geraldo, A.M. and Raimundo, W.F. "Physical-chemical changes during extraction and clarification of guava juice." Food Chemistry, vol. 54, no. 4, pp. 383-386, 1995.

14.Jackson, J.C., Bourne, M.C. and Barnard, J. "Optimization of blanching for crispness of banana chips using response surface methodology." Journal of Food Science, vol. 61, no. 1, pp. 165-166, 1996.

15.Joglekar, A.M. and May, A.T. "Product excellence through design of experiments." Cereal Foods World, vol. 32, pp. 857-868, 1987. 
16.Karangwa, E., Khizar, H., Rao, L., Nshimiyimana, D.S., Foh, M.B.K., Li. L., Xia, S.Q. and Zhang, X.M. "Optimization of processing parameters for clarification of blended carrot-orange juice and improvement of its carotene content." Advance Journal of Food Science and Technology, vol. 2, no. 5, pp. 268-278, 2010.

17.Kashyap, D.R., Vohra, P.K., Chopra, S. and Tewari, R. "Application of pectinases in the commercial sector: a review." Bio Resource Technology, 77, 215-227, 2001.

18.Khuri, A.I. and Cornell, J.A. "Response surface design and analysis." Marcel Dekker, Inc., New York, 1987.

19.Koocheki, A.S., Mortazavi, A., Shahidi, F., Razavi, S.M.A., Kadkhodaee, R. and Milani, J.M. "Optimization of mucilage extraction from qodume shirazi seed (Alyssum homolocarpum) using response surface methodology." Journal of Food Process Engineering, vol. 33, pp. 861-882, 2010.

20.Kumar, S., Sharma, H.K. and Sarkar, B.C. "Effect of substrate and fermentation conditions on pectinase and cellulose production by Aspergillus niger NCIM 548 in submerged (SmF) and solid state fermentation (SSF)." Food Science Biotechnology, vol. 20, pp. 1289-1298, 2011.

21.Lee, W.C., Yusof, S., Hamid, N.S.A. and Baharin, B.S. "Optimizing conditions for enzymatic clarification of banana juice using response surface methodology (RSM)." Journal of Food Engineering, vol. 73, no. 1, pp. 55-63, 2006.

22.Liew Abdullah, A.G.,Sulaiman, N.M., Aroua, M.K. and Megat Mohd Noor, M.J. "Response surface optimization of conditions for clarification of carambola fruit juice using a commercial enzyme." Journal of Food Engineering, vol. 81, no. 1, pp. 65-71, 2007.

23.Madden, D. "Enzymes in fruit juice production. In a jam out of juice. "Available from http://www.ncbe.reading.ac.uk/ncbe/protocols/inajam/pdf/jam01.pdf, Accessed January 10, 2000.

24.Mastrocola, D., Rosa, M.D. and Massini, R. "Freeze-dried strawberries rehydrated in sugar solutions: mass transfers and characteristics of final products." Food Research International, vol. 30, no. 5, pp. 359-364, 1997.

25.Mihalev, K., Schieber, A., Mollov, P. and Carle, R. "Effect of mash maceration on the polyphenolic content and visual quality attributes of cloudy apple juice." Journal of Agricultural Food Chemistry, vol. 52, no. 24, pp. 7206-7310, 2004.

26.Montgomery, D.C. Design and analysis of experiments, Wily, New York, pp. 416-419, 2001.

27.Moreno-Álvarez, M.J., Medina, C., Antón, L., García, D. and Belén-Camacho, D. "Uso de pulpa de tuna (Opuntia boldinghii) en la elaboración de bebidas cítricas pigmentadas." Interciencia, vol. 28, no. 9, pp. 539-543, 2003.

28.Myres, R.H. Response Surface Methodology, Department of Statistics, Virginia Polytechnic Institute and State University, Blacksburg, Virginia, Distributed by Edwards Brothers, Inc., Ann Arbor, Michigan, 1976.

29.Pagliarini, E., Peri, C., Zanoni, B. and Ghizzardi, M. "Optimisation of olive paste expression: maximizing yield by central composite design approach." Journal of Science and Food Agricultural, vol. 71, pp. 470-474, 1996.

30.Piga, A. Cactus pear : A fruit of nutraceutical and functional importance. Journal of the Professional Association for Cactus Development, vol. 6, pp. 9-22, 2004.

31.Pilnik, W. and Voragen, A.G.J. Pectic enzymes in juice manufacture. In : Enzymes in food processing (Nagodawithana, T. and Reed, G., Eds.), Academic Press, New York, 1993.

32.Rai, P., Majumda, G. C., Das Gupta, S. and De S. "Optimizing pectinase usage in pretreatment of mosambi juice for clarification by response surface methodology", Journal of Food Engineering, vol. 64, pp. 397-403, 2004.

33.Reyner, L. A. and Horne, J.A. "Efficacy of a 'functional energy drink' in counteracting driver sleepness." Physiology and Behavior, vol. 75, pp. 331-335, 2002.

34.Sáenz, C. Cactus Pear Juices. Paris: Annals of the 22nd IFU Symposium Paris, 2001.

35.Sáenz, C. and Sepúlveda, E. "Cactus pear juices." Journal of the Professional Association for Cactus Development, vol. 4, pp. 3-10, 2001.

36.Seidl, R., Peyrl, A., Nicham, R. and Hauser, E. "A taurine and caffeine-containing drink stimulates cognitive performance and well-being." Amino Acids, vol. 19, pp. 635-642, 2000.

37.Sharma, H.P., Patel, H. and Sharma, S. "Enzymatic extraction and clarification of juice from various fruits-a review." Trends in Post-Harvest Technology, vol. 2, no. 1, pp. 1-14, 2014.

38.Shelke, K., Dick, J.W., Holm, Y.F. and Loo, K.S. "Chinese wet noodle formulation: A response surface methodology study. Cereal Chemistry“, vol. 67, pp. 338-342, 1990.

39.Shyu, S.L. , L.S. "Effects of processing conditions on the quality of vacuum fried apple chips." Food Research International, vol. 34, pp. 133-142, 2001. 
40.Sin, H.N., Yusof, S., Hamid, N.S.A. and Rahman, R.A. "Optimization of enzymatic clarification of sapodilla juice using response surface methodology“, Journal of Food Engineering, vol. 73, pp. 313-319, 2006.

41.Singh, A. and Das Gupta, D.K. "Effect of enzyme concentration, temperature and time of treatment on the quality of plum juice", Process Food Industry, pp. 26-29, 2005.

42.Singh, A., Sanjay Kumar, H.K. "Effect of enzymatic hydrolysis on the juice yield from Bael fruit (Aeglemarmelos Correa) pulp." American Journal of Food Technology, vol. 7, no. 2, pp. 62-72, 2012.

43.Truong, V.D., Walter, W.M., Jr. and Bett, K.L. "Textural properties and sensory quality of processed sweet potatoes as affected by low temperature blanching." Journal of Food Science,vol. 63, no. 4, pp. 739-743, 1988.

44.Umsza-Guez, M.A., Rinaldi, R., Lago-Vanjela, E.S., Martin, N., Silva R.D., Gomes, E. and Thomeo, J.C. "Effect of pectinolitic enzymes on the physical properties of caja-manga (Spondias cytherea Sonn.) pulp." Ciência e Tecnologia de Alimentos, Campinas, vol. 31, no. 2, pp. 517-526, 2011.

45.Urlaub, R. "Advantages of enzymatic apple mash treatment and pomace liquefaction." Fruit Processing, vol. 6, pp. 399-406, 1996.

46.Vaillant, F., Millan, A., Dornier, M., Decloux, M. and Reynes, M. "Strategy for economical optimisation of the clarification of pulpy fruit juices using crossflow microfiltration." Journal of Food Engineering, vol. 48, pp. 83-90, 2001.

47.Vainionpaa, J. "Modelling of extrusion cooking of cereals using response surface methodology." Journal of Food Engineering, vol. 13, pp. 1-26, 1991.

48.Vaisey-Genser, M., Ylimaki, G. and Johnston, B. "The selection of levels of canola oil, water, and an emulsifier system in cake formulations by response surface methodology." Cereal Chemistry, vol. 64, pp. 50-54, 1987.

49.Vendrusculo, A.T., and Quadri, M.G.N. "Efeito dos tratamentos enzimático, termico e mecanico na estabilidade do suco de carambola (Averrhoa carambola L.)." Brazilian Journal of Food Technology, vol. 11, no. 1, pp. 28-34, 2008.

50.Wong, P.K., Yusof, S., Mohd Ghazali, H., and Che Man, Y. "Optimization of hot water extraction of Roselle juice by using response surface methodology: a comparative study with other extraction methods." Journal of the Science of Food and Agriculture, vol. 83, pp. 1273-1278, 2003.

51.Yusof, S., and Ibrahim, N. "Quality of soursop juice after pectinase enzyme treatment", Food Chemistry, vol. 51, no. 1, pp. 83-88, 1994.

52.Yusof, S., Talib, Z., Mohamed, S. and Abu Bakar, A. "Use of response surface methodology in the development of guava concentrate." Journal of Science and Food Agricultural, vol. 43, pp. 173-186, 1988. 